\title{
INSTAGRAM SEBAGAI ALAT PENILAIAN KETRAMPILAN BERBICARA DAN STRATEGI PENINGKATKAN KETERLIBATAN PESERTA DIDIK DALAM PEMBELAJARAN BAHASA INGGRIS DI KELAS 7.1 SMP N 6 AMBON
}

\author{
Helena Magdalena Rijoly ${ }^{1}$ \& Emelia M. Tuhumury ${ }^{2}$ \\ rijolyhelena@yahoo.co.uk meggyegy79@gmail.com
}

\begin{abstract}
Pembelajaran Bahasa Inggris disekolah perlu menggunakan cara-cara kreatif dan aktif untuk membantu peserta didik mencapai kompetensi baik yang diisyarakan dalam kurikulum maupun kompetensi actual yang akan diukur berdasarkan kemampuan peserta didik/lulusan di dunia nyata. Untuk memastikan bahwa kompetensi, baik kompetensi pengetahuan dan kompetensi ketrampilan telah dicapai, Kurikulum 2013 menekankan penilaian ketrampilan yang holistic dan individual. Guru diharapkan mampu untuk menyediakan penilaian menyeluruh untuk setiap peserta didik di kelasnya. Demikian juga, guru diharapkan mampu memfasilitasi proses pembelajaran yang memastikan peserta didik dapat mengembangkan kompetensi ketrampilannya, dalam hal ini kompetensi berbicara. Disisi lain, proses pembelajaran dikelas terbentur dengan singkatnya durasi tata muka. Penelitian Tindakan Kelas (PTK) ini mencoba menggunakan Instagram sebagai alat penilaian ketrampilan berbicara dan sebagai strategi untuk meningkatkan keterlibatan peserta didik dalam pembelajaran Bahasa Inggris di jenjang kelas VII. Hasil penelitian menunjukan bahwa penggunaan Instagram sebagai Alat Penilai Ketrampilan Berbicara sangat efektif untuk guru sedangkan bagi siswa hasil menunjukan bahwa mereka mnyukai penggunaan strategi ini karena menyenangkan dan mempu membangun rasa percaya diri dan ketrampilan berbicara. Tentu saja, masih banyak hambatan dan tantangan yang dihadapi dan masukan dari PTK ini akan sangat berguna untuk penyempurnaan penggunaan dimasa yang akan datang.
\end{abstract}

Kata Kunci : Pembelajaran Bahasa Inggris, Alat Penilaian Ketrampilan, Ketrampilan Berbicara, Strategi Keterlibatan Siswa

\section{Pendahuluan}

Ada 3 hal yang berkembang sangat pesat di zaman millennium ini, yaitu: aksesibilitas akan gawai pintas, aksesibilitas koneksi internet dan keterpaparan pada Bahasa asing khususnya Bahasa Inggris. Yang dimaksudkan dengan aksesibilitas gawai pintar adalah bahwa jenis gawai semakin beraneka ragam dengan kemampuan yang hamper sama dan dengan harga yang semakin terjangkau. Rata-rata kebutuhan 'kepintaran' gawai yang ramai di cari adalah kemampuan koneksi internet cepat, kemampuan untuk mengambil foto dan video

\footnotetext{
${ }^{I}$ Helena Magdalena Rijoly is Lecturer at English Department, Pattimura University, AmbonMaluku Indonesia

${ }^{2}$ Emelia M. Tuhumury is Teacher at SMP Negeri 6 Ambon
} 
dengan kualitas baik, daya memory besar serta kemampuan untuk mengisi daya (charging) cepat dan tahan lama. Aksesibiltas koneksi internet yang dimaksudkan adalah ketersediaan jaringan dengan kualitas yang semakin baik hingga kecepatan 4G dan biaya pulsa yang semakin murah dengan banyaknya paket-paket internet cepat yang ditawarkan. Disisi lain, dengan semakin terbukanya jalur komunikasi dan informasi, generasi sekarang terpapar secara terus menerus kepada Bahasa asing, khususnya Bahasa Inggris yang mereka serap lewat lagu film, iklan, sosmed dll.

Bahasa Asing, khususnya Bahasa Inggris menjadi suatu kebutuhan yang tidak bisa ditawar lagi. Bahasa ini menjadi tolak ukur untuk penerimaan pegawai, penerimaan beasiswa dll (Zaremba, 2006; Osborn et.al, 2008). Generasi sekarang dituntut untuk menguasai Bahasa ini bukan hanya dalam ranah pengetahuan namun juga dalam ranah ketrampilan aktif. Untuk itu pembelajaran Bahasa Inggris di sekolah dituntut untuk mampu mempersiapkan lulusan yang memiliki kualitas kemampuan dan ketrampilan seperti ini untuk dapat bersaing di tingkat nasional maupun global.

Pembelajaran Bahasa Inggris merupakan salah satu mata pelajaran wajib di tingkat pendidikan formal di Indonesia. Dibawah payung Kurikulum K-13, Bahasa Inggris mulai diajarkaan di jenjang SMP. Di Jenjang Sekolah Dasar, mata pelajaran Bahasa Inggris tidak wajib dan dikategorikan sebagai mata pelajaran muatan local. Sekolah yang siap dapat menjalankannya dan sekolah yang belum siap bias tidak menjalankannya. Hal ini disebabkan bahwa tidak semua daerah di Indonesia memiliki sarana dan sumber daya pendukung untuk memberikan pelajaran Bahasa Inggris (Ramon Mohandas, Kepala Pusat Kurikulum dan Perbukuan Kemendikbud dalam Republika.co.id, 2018).

\section{Pembelajaran Bahasa Inggris Di Tingkat SMP}

Pembelajaran Bahasa Inggris di jenjang SMP dalam payung kurikulum 2013 dirancang untuk menyongsong model pembelajaran abed ke-21 (Wachidah et.al. 2017). Proses pembelajarannya ditujukan untuk menigkatkan kemampuan bahsa Inggris lewat penyajian yang berbasis teks lisan atau tertulis dan pengolahan rasa. Pembelajaran dimulai dengan peningkatan kompetensi pengetahuan dan dilanjutkan dengan kompetensi ketrampulan.

Penekanan pada dua kompetensi ini adalah sangat beralasan karena kemampuan berbahasa yang dibutuhkan saat ini tidak hanya dalam ranah pengetahuan namun mereka harus juga terampil dalam menggunakannya dengan tepat pada situasi dan konteks yang benar pula.

Untuk itu, guru sebagai fasilitator pembelajaran didorong untuk memperkenalkan peserta didik kepada berbagai jenis metode dan startegi pengajaran serta sumber-sumber belajar yang bervariasi. Sumber-sumber belajar pada abad 21 bukan hanya diterima dari guru di kelas atau dari buku namun juga dari lingkungan sekitar dan dari teknologi informasi dan komunikasi yang berkembang dengan sangat pesatnya. Ang meliputi aspek sikap, pengetahuan dan ketrampilan 
Sebagai sebuah kurikulum yang menitikberatkan kepada kompetensi maka Kurikulum 2013 menerapkan penilaian otentik. Wachidah et.al. (2017) menjabarkan hal-hal mendasar pada penilaian autentik, yaitu:

- Penilaian menjadi bagian yang tidak terpisahkan dari pembelajaran

- Menggunakan beberbagai cara dan kriteris

- Holistic (kompetensi utuh merefleksikan pengetahuan, ketrampilan dan sikap

- Peserta didik membangun responnya sendiri, bukan sekedar memilih dari yang tersedia.

- Tugas merupakan tantangan yang ada atau yang mirip dihadapi dalam dunia nyata

- Tugas yang tidak hanya memiliki satu jawaban tertentu yang benar.

Dengan demikian, ada beberapa hal yang perlu dipahami dari pola pembelajaran Bahasa Inggris dalam kurikulum 2013. Pertama, pola pembelajaran diharapkan aktif dan interaktif untuk mendorong pengembangan kompetensi pengetahuan dan ketrampilan. Dalam hal ini, guru tidak lagi diharapkan menjadi sumber satu-satunya pengetahuan dalam kelas dan diharapkan mampu untuk mengarahkan peserta didik untuk mempu mengeksplorasi dan memecahkan masalah sendiri (King, 1993). Kedua, sumber belajar diarahkan untuk kontekstual dan actual serta dekat dengan 'dunia' peserta didik untuk mempu mengefektifkan proses belajar dan memotivasi belajar siswa (Curtain, 1994). Ketiga, penilaian perlu dilakukan untuk masing-masing siswa secara actual, holistic dan dalam lebel HOT (Higher Order Thinking).

\section{Deksripsi Umum Dan Tantangan Pembelajaran Bahasa Inggris Di Ambon, Maluku}

Pembelajaran Bahasa Inggris di Ambon, Maluku khususnya di SMP Negeri 6 Ambon, berjalan seperti yang dialamatkan dalam Kurikulum 2013. Sekolah SMP 6 sendiri adalah juga sekolah rujukan yaitu sekolah yang dirujuk pemerintah untuk membina sekolah disekitarnya tentang bagaimana pembelajaran dan pengelolaan sekolah yang baik (Kemdikbud, 2018).

Pembelajaran Bahasa Inggris di SMP 6 secara khusus pada kelas VII. 1 dilaksanakan 2 kali seminggu dengan alokasi total 4 JP dan dengan durasi waktu 30 menit per JP. Dengan demikian total waktu pembelajaran Bahasa inggris disekolah adalah 120 menit atau 2 jam saja.

Kelas VII.1 terdiri dari 33 peserta didik yang duduk dalam formasi kelas tradisional, yaitu 2 baris berisi 4 bangku yang menghadap kedepan. Papan tulis dan meja guru berada didepan kelas dalam posisi di tengah dan dengan undakan elevasi yang lebih tinggi dari tempat duduk peserta didik.

Kelas VII.1 adalah kelas 1 SMP dan merupakan siswa baru yang baru berpindah dari SD. Secara karakter belajar, mereka masih transisi dari pola belajar di SD ke SMP. Dengan demikian, karakter cerewet, bermain-main dan cepat hilang fokus teramati secara hamper menyeluruh pada peserta didik.

Observasi awal dan orientsi sekolah menunjukan beberapa tantangan yang dihadapi guru dan peserta didik dalam proses pembelajaran di sekolah. Beberapa diantaranya adalah: 
- Durasi belajar di kelas terlalu singkat

- Karena durasi belajar yang singkat ini maka peserta didik tidak mempunyai waktu dan tidak bias diberikan kesempatan untuk dapat praktek perorangan dan menerima feedback dari guru. Disisi lain, guru juga menyebutkan bahwa durasi waktu yang dingkat ini tidak memberikan kesempatan bagi mereka untuk membuat dan memberi penilaian kepada masing-masing siswa ataupun untuk melakukan elaborasi dan pendalaman materi.

- Sementara, Kurikulum 2013 menuntut adanya penilaian ketrampilan dengan adanya rubric penilaian ketrampilan dalam RPP.

Tantangan-tantangan ini mengalamatkan bahwa pembelajaran Bahasa Inggris dikelas membutuhkan alat atau instrument (Tool) pendukung penilaian dan strategi (strategy) untuk meningkatkan keterlibatan peserta didik.

Alat/tool dan strategy/strategy yang dibutuhkan memiliki karakteristik kebutuhan sebagai berikut:

1. Dapat digunakan sebagai Off-Class activity atau kegiatan diluar jam pelajaran disekolah. Hal ini dikarenakan bahwa durasi waktu yang disediakan dalam kurikulum (4 jam/minggu) tidaklah mencukupi untuk dapat mencapai sasaran kompetensi yang ditentukan oleh kurikulum. Kurikulum 2013 mengakomodasi hal ini dengan adanya penilaian Penugassan terstruktur dan tidak terstruktur.

2. Harus dekat dengan 'dunia' peserta didik dan dapat diterima sebagai sesuatu yang menyenangkan untuk digunakan oleh siswa kelas VII SMP.

Salah satu solusi yang dapat menjawab tantangan dan kebutuhan diatas adalah dengan mengadaptasi strategi Flipped Classroom atau Blended Learning. Karena baik Flipped Classroom maupun Blended Learning mendukung terciptanya kondisi pembelajaran yang dilakukan diluar kelas dan mendukung pelaksanaan proses belajar di kelas. Penggunaan strategi ini dimungkinkan karena kepemilikan gawai pintar dan aksesibilitas koneksi internet di Ambon, Maluku dan terutama di kelas VII.1 merata. Hasil survey kelas membuktikan bahwa semua siswa kelas VII.1 memiliki ponsel pintar (smartphone) dan hamper semuanya (minus 2 orang) dapat digunakan untuk mengakses internet. 2 orang yang HP-nya tidak bisa mengakses internet mengakui bahwa mereka biasanya dan sering menggunakan computer dan laptop dirumah dan di warnet/Telkom. Survey kelas juga membuktikan bahwa semua peserta didik memiliki akun Instagram dan secara aktif menggunakannya. Demikian juga disisi lain, guru memiliki ponsel pintar dan memiliki akun aktif Intagram.

Atas pertimbangan-pertimbangan diatas maka penggunaan Instagram ditawarkan sebagai alat/instrument (tool) penilaian ketrampilan khususnya ketrampilan berbicara dan sebagai strategi untuk meningkatakan keterlibatan peserta didik dalam pembelajaran Bahasa Inggris, dalam hal ini, untuk peningkatkan kompetensi ketrampilan.

\section{Instagram Sebagai Alat (Tool) Dan Strategi (Strategy) Dalam Pembelajaran Bahasa Inggris.}

Pusat Bantuan Instagram (Instagram.com) menyebutkan Instagram sebagai aplikasi social networking atau jejaring sosial yang dikhususkan untuk berbagi 
foto dan video secara gratis dan tersedia di perangakat Apple iOS, Android dan Windows Phone.

Dalam berbagi foto dan video, pengguna dapat menambahkan tagar (hashtag) atau \# di keterangan atau komentar. Tagar yangdibubuhkan akan mengakibatkan postingan pengguna terlihat di halaman tagar yang sesuai,

Dalam Penelitian Tindakan Kelas (PTK) kali ini, instagram dipilih sebagai alat/instrument (tool) penilaian ketrampilan khususnya ketrampilan berbicara dan sebagai strategi untuk meningkatakan keterlibatan peserta didik berdasarkan beberapa alasan berikut ini:

1. Hasil survey membuktikan bahwa Instagram adalah platform yang digunakan oleh semua siswa kelas VII.1. Mereka mempunyai akun dan aktif menggunakan untuk mem-posting foto/video)

2. Platform Instagram menggunakan sistem Hashtag/tagar (\#) sehingga video2 dapat terdokumentasi dan ter-archived untuk pencarian cepat

3. Video di Instagram berdurasi pendek (1 menit) yang sesuai dengan kebutuhan kelas dimana siswa diminta untuk mempu menggunakan fungsi Bahasa dalam kontek penggunaan sebenarnya

4. Privacy: dengan menggunakan IG guru tidak perlu membuat group kelas tersendiri atau harus berteman dengan semua siswa untuk dapat mengakses video-video tersebut. Hanya dengan menggunakan \# untuk dapat posting dan mengakses. Profil dosen juga bisa dilock jika tidak ingin disebarluaskan.

5. Aksesibilitas Internet semakin baik diseluruh Maluku khususnya di Ambon

Beberapa keuntungan dan dampak positif yang diharapkan terjadi melalui penggunaan Instagram sebagai alat/instrument (tool) penilaian ketrampilan khususnya ketrampilan berbicara dan sebagai strategi untuk meningkatakan keterlibatan peserta didik adalah sebagai berikut:

1. Guru diharapkan mendapat pengalaman dalam penerapan Technology Enhanced Language Learning untuk memperkaya proses belajar mengajar

2. Guru diharapkan mempunyai data kongkrit perkembangan anak dalam ketrampilan berbicara

3. Guru diharapkan mendapatkan data 'error habit' dalam Penggunaan Bahasa Inggris dari peserta didiknya yang kemudian dapat digunakan baseline untuk pengayaan dan pendalaman materi di kelas, maupun untuk penelitian selanjutnya

4. Siswa diharapkan mendapatkan kesempatan berlatih dan menggunakan dalam suasana dan format yang sesuai dengan dunia mereka.

5. Siswa diharapkan termotivasi untuk terlibat aktif dalam proses BM dan juga mendapat kesempatan untuk belajar dari teman lain.

6. PTK ini diharapkan dapat memberikan gambaran awal efektifitas dan efisiensi penggunaan Platform Instagram untuk menunjang pembelajaran Bahasa Inggris untuk konteks Ambon. 


\section{Metodologi}

Penelitian ini menggunakan metodologi Penelitian Tindakan Kelas (PTK). PTK merupakan suatu metode penelitian yang dilakukan oleh guru kelas secara pribadi maupun dengan kolaborasi yang mengarah kepada solusi praktis untuk mengatasi masalah dan tantangan yang ditmui dalam kelasnya, peningkatan kapasitas dan kompetensi guru dan dilakukan secara sistematis dan terstruktur (Koshy, 2005; Ur, 1996; Borg, Gall and Gall, 1993; Kemmis and Taggart, 1998)

PTK ini memiliki 3 research questions yang menjadi hal yang ingin digali lewat PTK ini, yaitu:

1. Bagaimanakah cara menggunakan Instagram sebagai Alat bantu Penilaian Ketrampilan Berbicara untuk mata pelajaran Bahasa Inggris Kelas VII?

2. Bagaimanakah cara menggunakan Instagram sebagai strategi peningkatan keterlibatan peserta didik dalam pembelajaran Bahasa Inggris kelas VII?

3. Apa tantangan dan keuntungan dari penggunaan Instagram sebagai alat penilaian ketrampilan berbicara dan sebagai strategi peningkatan keterlibatan peserta didik dalam pembelajaran Bahasa Inggris?

PTK dilakukan pada kelas VII.1 SMP Negeri 6 Ambon dengan jumlah siswa 33 orang. PTK ini dilakukan dalam salah satu tahapan program Penugasan Dosen di Sekolah tahun 2018 yaitu pada tahapan Pelaksanaan Pembelajaran. Dalam tahapan ini, dosen harus melaksanakan 8 kali mengajar di kelas dan PTK dilaksanakan dalam kurun waktu ini. Guru kemudian mereplikasi praktek penggunaanya di kelas lain. Namun hasil dari replikasi guru tersebut tidak dimasukan dalam laporan PTK kali ini.

Kemmis and Taggart (1998) menyebutkan bahwa PTk dilakukan dalam bentuk tahapan yang disebut 'Cycle' atau siklus. Dalam setiap siklus ada tahapantahapan yang dilakukan, yaitu:

1. Identifikasi masalah

2. Perencanaan Penelitian

3. Pelaksanaan dan Pengumpulan data

4. Analisa dan Interpretasi Data

5. Refleksi hasil (Identifikasi masalah dan perencanaan untuk siklus berikutnya)

PTK ini akan menggunakan RPP 5 (Introducing Yourself), RPP 6 (Introducing Others) dan RPP 7 (talk about family). Grammar yang akan difokuskan adalah Pronoun (Personal dan Possessive), Auxiliary Verbs dan Subject-Verb Aggrement. Peserta Didik kemudian diberikan Penugasan Terstruktur dalam bentuk Project Pembuatan Video. Video tersebut diunggah ke Instagram dengan menggunakan hashtag yang ditentukan. Langkah-langkah pelaksanaan adalah sebagai berikut:

1. Guru memberikan materi dan memfasilitasi belajar seperti biasa di kelas dengan mengiktui RPP yang dibuat. Peserta didik menyimak dan berpartisipasi aktif dalam proses belajar mengajar

2. Guru memberikan dan menjelaskan Tugas project pembuatan video kepada peserta didik. Video akan dimasukan lewat Instagram dengan menggunakan tagar/hashtag yang ditentukan. 
3. Peserta didik membuat video dirumah atau diluar kelas dan mengunggah ke Instagram dengan menggunakan hastag/tagar yang ditentukan pada batas waktu yang diminta

4. Guru menonton hasil video, memberikan penilaian dan jika memungkinkan memberikan feedback online. Jika tidak, feedback akan dilakukan langsung dikelas.

5. Guru melakukan refleksi hasil penggunaan Instagram.

Untuk mengukur keberhasilan penggunaan Instagram maka ditentukan indikator kesuksesan setiap cycle sebagai berikut:

- 100\% peserta didik memasukan tugas Project Pembuatan Video sesuai dengan topik/tema dan dengan menggunakan Hashtag/tagar yang ditentukan. Batas minimum indicator keberhasilan adalah $70 \%$ peserta didik memasukan Tugas dengan hashtag/tag IG yang ditentukan

- Ketrampilan berbicara Masing-masing siswa dapat dilakukan dan terdokumentasikan. Rubrik (aspek dan standar) penilaian mengikuti yang ada dalam RPP.

- Indikator tambahan/pendukung adalah minimal 70\% siswa mendapat nilai diatas $70 \%$.

Instrumen pengumpulan data tambahan yang digunakan adalah Angket Survey, Questionaire, Observation Checklist dan Interview. Questionaire digunakan 1 kali untuk mendapatkan data peserta didik, kepemilikan gawai dan akses internet, kebiasaan online dan pengalaman pembelajaran Bahasa inggris. Angket survey digunakan 2 kali: untuk menelusuri tantangan yang dihadapi pada siklus pertama dan untuk mendapatkan feedback pada akhir PTK. Interview digunakan untuk lebih memahami aspek dan tantangan yang terjadi dalam PTK.

\section{Hasil Penelitian Dan Pembahasan}

\section{Pelaksanaan Siklus 1}

Materi yang dibawakan adalah dari RPP 5 Memperkenalkan diri sendiri. Peserta didik mempelajari fungsi Bahasa yaitu struktur kalimat untuk memperkenalkan diri: nama, tempat tinggal, alamat dan asal. Siswa juga dilatih pengucapan (pronounciation) dan Intonasi (intonation). Materi ini dibawakan dalam 2 kali pertemuan. Siswa kemudian diberikan penugasan terstruktur lewat project pembuatan video dimana mereka diminta untuk memperkenalkan diri mereka dan mengunggahnya ke Instagram menggunakan hashtag/tagar \#smp6introducingme. Peserta didik diberikan waktu 1 minggu untuk memposting hasil video mereka.

\section{Hasil Siklus 1}

Dari 33 siswa hanya 22 video $(66 \%)$ memasukan tugas project pembuatan video. Dengan demikian penilaian ketrampilan berbicara hanya dapat dilakukan bagi 22 peserta didik (66\%). Hasil penilaian kemampuan berbahasa Inggris mereka dapat dilihat pada tabel berikut ini: 


\begin{tabular}{|c|c|}
\hline Kategori nilai & Jumlah \\
\hline $\begin{array}{c}\text { Sangat Baik (85- } \\
\mathbf{1 0 0 \% )}\end{array}$ & 10 \\
& $(45.45 \%)$ \\
\hline Baik (70 - 85\%) & 12 \\
\hline $\begin{array}{c}\text { Cukup (55 - } \\
\mathbf{7 0 \% )}\end{array}$ & 0 \\
\hline $\begin{array}{c}\text { Kurang (40 - } \\
\mathbf{5 5 \% )}\end{array}$ & 0 \\
\hline Buruk (0-40 \%) & 0 \\
\hline
\end{tabular}

Hasil ini menunjukan bahwa tingkat pembuatan dan pemasukan tugas masih belum memenuhi indicator kesuksesan. Meskipun hasil penilaian dapat dilakukan untuk masing-masing anak, namun jumlah ini bukanlah keseluruhan jumlah populasi kelas. Hal ini berarti guru belum dapat membuat penilaian ketrampilan berbicara bagi semua siswa dalam kelas. Disisi lain, dapat dilihat bahwa untuk materi memperkenalkan diri sendiri, siswa sudah dapat memahami dan mempraktekan dengan melampaui batas minimal indicator keberhasilan.

Angket Survey pertama menelusuri masalah yang terjadi sehingga jumlah pemasukan video tidak memenuhi indicator kesuksesan. Masalah yang dikemukakan oleh peserta didik adalah sebagai berikut:

1. Mereka lupa mengerjakan tugas (lupa tugas dan lupa deadline)

2. Mereka tidak diberikan ijin oleh orang tua untuk menggunakan Instagram/Sosial Media.

3. Mereka tidak memiliki akses internet (Tidak ada pulsa data)

4. HP yang tiba-tiba rusak / file video yang tiba-tiba rusak

Jawaban-jawaban ini tentu saja ada yang merupakan alasan yang dibuatbuat karena jika ditilik dari aktifitas IG mereka, mereka masih aktif memposting.

Angket Survey juga menanyakan pendapat mereka apakah Instagram masih bisa digunakan dana pa saran mereka untuk perbaikan kedepan. Semua peserta didik dengan antusias menjawab bahwa mereka tetap mau menggunakan Instagram untuk tugas video. Namun ada beberapa saran yang mereka berikan.

- guru/dosen perlu membantu menghubungi orang tua

- Memberikan penjelasan dan pelatihan sekali lagi tentang bagaimana melakukannya

- Mengingatkan siswa terus untuk deadlinenya dan memberikan hukuman jika tidak melakukannya

Refleksi Siklus 1 dan Rekomendasi untuk Siklus II

Pelaksanaan siklus satu masih belum berhasil dengan maksimal. Beberapa hambatan telah teridentifikasi dan didiskusikan. Dari pengalaman siklus I, PTK ini merekomendasikan hal-hal berikut ini untuk diperhatikan dalam perencanaannya.

1. Membuat Information Package untuk Orang Tua - Informasi project, waktu pelaksanaan, produk dan penilaian. Dengan demikian orang tua 
mendapatkan informasi dapat mengijinkan anak berpartisipasi aktif dalam mengerjakan tugas.

2. Membuat Panduan Project bagi Guru dan Siswa. Hal ini dilakukan agar ada kejelasan baik kepada siswa dan guru dalam hal penggunaan strategi ini.

3. Kesempatan untuk memposting lewat IG orang tua, teman, keluarga dll selama menggunakan \# yang ditentukan. Dengan demikian, masalah tidak adanya akses dan koneksi bisa teratasi.

\section{Pelaksanaan Siklus II}

Materi yang dibawakan adalah dari RPP 7 Anggota keluarga dan silsilah keluarga. Peserta didik mempelajari fungsi Bahasa yaitu struktur kalimat untuk memperkenalkan anggota keluarga: nama, tempat tinggal, umur dan hobby. Siswa juga dilatih pengucapan (pronounciation) dan Intonasi (intonation). Materi ini dibawakan dalam 2 kali pertemuan. Siswa kemudian diberikan penugasan terstruktur lewat project pembuatan video dimana mereka diminta untuk memperkenalkan diri mereka dan mengunggahnya ke Instagram menggunakan hashtag/tagar \#smp6introducingfamily. Peserta didik diberikan waktu 1 minggu untuk memposting hasil video mereka.

Untuk pelaksanaan kali ini telah dibuat information package dan panduan project yang didalamnya juga dijelaskan kesempatan untuk memposting lewat akun IG orang lain.

\section{Hasil Siklus 11}

Dari 33 siswa, terjadi peningkatan untuk yang memasikan video menjadi 27 video $(81.81 \%)$. Dengan demikian penilaian ketrampilan berbicara hanya dapat dilakukan bagi 22 peserta didik (81.81\%). Hasil penilaian kemampuan berbahasa Inggris mereka dapat dilihat pada tabel berikut ini:

\begin{tabular}{|c|c|}
\hline Kategori nilai & Jumlah \\
\hline $\begin{array}{c}\text { Sangat Baik (85- } \\
100 \%)\end{array}$ & $\begin{array}{c}13 \\
(48.14 \%)\end{array}$ \\
\hline Baik $(70-85 \%)$ & $\begin{array}{c}12 \\
(44.44 \%)\end{array}$ \\
\hline $\begin{array}{c}\text { Cukup (55 - } \\
70 \%)\end{array}$ & $2(7.40 \%)$ \\
\hline $\begin{array}{c}\text { Kurang }(40- \\
55 \%)\end{array}$ & 0 \\
\hline Buruk (0-40 \%) & 0 \\
\hline
\end{tabular}

Hasil ini menunjukan bahwa tingkat pembuatan dan pemasukan tugas sudah melampaui batas indicator kesuksesan minimum (70\%) dengan mencapai 81.81\%. Penilaian ketrampilan berbicara bagi masing-masing anak pun dapat dilakukan. Walaupun telah mengalami peningkatan namun jumlah ini bukanlah keseluruhan jumlah populasi kelas. Hal ini berarti guru belum dapat membuat penilaian ketrampilan berbicara bagi semua siswa dalam kelas. Dari sisi materi, terlihat 
bahwa materi memperkenalkan keluarga telah mampu dikuasai oleh siswa dengan melampaui batas minimal indicator keberhasilan.

Angket Survey kedua yang dilakukan di akhir siklus II tingkat persetujuan peserta didik atas penggunaan Instagram, hambatan ketika tidak bisa memasukan tugas dan apakah project ini dapat membantu peningkatan kemampuan Bahasa Inggris mereka. Dari total 33 siswa, angket hanya diisi oleh 30 siswa karena 3 orang sedang sakit dan ijin. Hasilnya adalah sebagai berikut:

1. Peserta didik diminta pendapat atas seberapa sukanya mereka untuk menggunakan IG untuk penugasan terstruktur. Sangat suka 14 orang $(46.7 \%)$, Suka 10 orang $(33.3 \%)$, Kurang suka 6 orang $(20 \%)$ dan tidak suka 0 orang.

2. Alasan yang mereka berikan atas tingkat kesukaan mereka bervariasi. Sebagian besar menyatakan bahwa mereka senang bisa eksis di Instagram dengan mempostik video berbahasa Inggris serta mendapat kesempatan dinilai oleh guru. Ada beberapa peserta didik yang menyatakan kurang suka dengan alasan bahwa mereka pemalu, tidak suka mengekspos diri sendiri dan bahwa tugas ini merepotkan (1 orang).

3. 16 orang $(53.3 \%)$ menyatakan bahwa tidak ada hambatan sama sekali untuk menyelesaikan tugas seperti ini. Sisanya memberikan alasan bahwa mereka tidak ada pulsa data, dilarang orang tua dan suka lupa/tidak punya waktu.

4. Ketika ditanya apakah tugas memposting video lewat Instagram dapat membantu dan menungkatkan kemampuan Bahasa Inggris mereka 4 orang (13.3\%) menyatakan kurang bisa membantu karena hanya memposting tidak mendapatkan pelajaran ( 2 orang), tidak suka posting video di sosial media (1 orang) dan durasi video terlalu singkat untuk dapat meningkatkan kemampuan (1 orang).

\section{Kesimpulan}

Ketika memulaim PTK ini memiliki 3 tujuan yang tergambar lewat research question, yaitu: 1) menjelaskan cara peenggunaan Instagram sebagai alat penilaian ketrampilan berbicara, 2) menjelaskan cara penggunaan Instagram sebagai strategi peningkatan keterlibatan peserta didik dalam pembelajaran Bahasa Inggris dan 3) menjabarkan tantangan dan keuntungan penggunaan Instagram sebagai alat penilaian ketrampilan berbicara dan sebagai strategi untuk meningkatkan keterlibatan peserta didik. Untuk itu, bagian ini akan menjawabnya satu per satu.

Penggunaan Instagram Sebagai Alat Penilaian Ketrampilan Berbicara

Alat penilaian adalah intrumen yang digunakan untuk mengumpulkan data dan menilai tingkat capaian pembelajaran (GallaudetU, 2018). Instagram digunakan sebagai salah satu dari 2 instrument yang digunakan secara berpasangan. Instagram sebagai tempat/wadah memposting produk akhir peserta didik dan Rubrik penilaian untuk menilai tercapai tidaknya target serta untuk menjamin penilaian yang obyektif.

Seperti yang disuarakan oleh seorang peserta didik dalam meresponi angket survey yang mengatakan bahwa Intagram tidak/kurang membantu untuk meningkatkan kemampuan berbahasa Inggris. Hal ini benar, jika guru hanya 
menggunakan Instagram saja dan hanya meminta siswa untuk memposting tanpa ada tindakan lanjutanya. Penggunaan Instagram dapat bermakna dalam kasus ini jika video yang diposting itu dilihat oleh guru, dianalisa dan kemudian guru memberikan feedback kembali kepada siswa. Dengan demikian penggunaan Instagram sebagai salah satu instrument belajar dan penilaian dapat terpenuhi. Hal ini dikarenakan, proses ini menjadi bermakna - meaningful learning (Krashen, ...).

Dari sisi administrasi dan proses pembelajaran, penggunaan Instagram dalam kasus ini memiliki banyak manfaat. Yang pertama, guru memiliki bukti otentik yang tersedia spenajang waktu (selama tidak dihapus) dan juga terkategorisasi dan dapat ditemukan dengan cepat dikarenakan penggunaan hastag/tagar yang unik. Guru dapat menggunakan ini sebagai bukti portfolio mengajar, dapat memberikan bukti kepada orang tua, dapat menggali kesulitan belajar/materi yang kemudian akan dilakukan pengayaan dikelas. Selain dari pada itu, video memudahkan guru untuk mengidentifkasi kesulitan masing, masing peserta didik serta melihat error habit dalam ketrampilan berbicara.

Penggunaan Instagram Sebagai Strategi Peningkatan Keterlibatan Peserta Didik

Ketika diberikan kesempatan untuk praktek dikelas, biasanya yang paling sering terlibat adalah peserta didik yang dominan dan vokal. Mereka sudah mempunyai rasa percaya diri tinggi serta memiliki kemampuan yang sudah bisa ditampilkan. Namun kelompok ini hanyalah 5\% dari keseluruhan jumlah siswa dikelas. Terkadang karena kebutuhan kita untuk memenuhi target waktu yang sangat singkat, siswa yang pasif dan tidak percaya diri tidak mendapat kesempatan serta memiliki alasan untuk tidak mendorong diri mereka untuk keluar dari zona nyaman.

Fenomena ini terjadi di semua kelas dan di mata pelajaran manapun. Penggunaan Instagram memberikan kesempatan dan tuntutan yang sama kepada semua peserta didik untuk berlatih dan menampilkan kemampuan diri mereka. Hasil PTK menunjukan bahwa siswa menganggap strategi ini baik karena satu sebagai milenial, urusan eksis di sosial media menjadi sebuah 'kebutuhan' (Prensky, 2001). Dan ketika kebutuhan itu bisa dinaikan derajatnya dengan 'eksis' dengan Bahasa asing, maka strategi ini dipastikan akan disambut baik oleh generasi milenial. Lebih dari setengah populasi penelitian mengakui bahwa hal ini menumbuhkan rasa percaya diri mereka. Dan studi menunjukan bahwa dalam hal mempelajari Bahasa Asing level terampil bisa dicapai jika peserta didik memiliki rasa percaya diri yang baik (Trent, 2009.

\section{Tantangan Dan Keuntungan Penggunaan Instagram}

Hasil PTK ini dinilai berhasil karena telah mampu melampaui batas minimum indicator kesuksesan. Namun, dengan tidak tercapainya kondisi $100 \%$, menyatakan bahwa masih banyak hal yang perlu diperbaiki, ditingkatkan dan dirubah. Bagian ini akan menjawab research question yang ketiga sekaligus sebagai rangkuman dan rekomendasi untuk penelitian dan penggunaan selanjutnya.

Beberapa tantangan dan keutungan penggunaan Instagram baik sebagai alat penilai ketrampilan berbicara maupun sebagai strategi keterlibaan peserta didik dalam pembelajaran telah dibahas lewat pembahasan 2 research question diatas. 
Bagian ini akan menjabarkan rangkuman tantangan yang perlu dipertimbangkan oleh guru, dosen, peneliti atau pihak mana saja yang akan menggunakan Instagram dimasa yang akan datang.

1. Untuk jenjang SMP, sangat penting untuk melibatkan orang tua untuk mendapatkan persetujuan dan ijin (consent) penggunaan Sosial media (Instagram) dan juga dapat memantau penggunaan gawai dan perkembangan belajar anak.

2. Perlu meluangkan waktu untuk memberikan pelatihan singkat Literasi Teknologi, Informasi dan Komunikasi baik untuk peserta didik maupun guru. Sehingga mereka familiar dengan tata cara dan etika penggunaan Instagram baik sebagai jejaring sosial maupun sebagai alat dan strategi pembelajaran.

3. Diperlukan perencanaan yang matang mulai dari pelatihan (poin 2 diatas), pemberian tugas, monitoring pemasukan tugas hingga penilaian.

4. Masalah aksesibilas koneksi internet serta kepemilikan gawai perlu menjadi pertimbangan serius dikarenakan ini adalah variable utama untuk dapat berjalan dengan baik.

5. Guru dan siswa dapat juga mencoba menggunakan platform lain untuk menunjang pembelajaran dikelas.

\section{Daftar Rujukan}

Borg, W., et. al. (1993). Applying Educational Research: A Practical Guide. New York: Longman.

Curtain, H and Pesola, S.A.B. (1982). Language and Children: Makung the Match. London: Longman.

Instagram.Inc. (2018). Bagaimana Cara Mengunakan Instagram. Instagram Help Desk https://help.instagram.com accessed on 23 October 2018.

Kemmis, K. and McTaggart, R. (2000). Participatory Action Research. Oxford: OUP

King, A. (1993). From Sage on the Stage to Guide on The Side. College Teaching, 4/(1), 30-35.

Koshy, V. (2005). Action Research for improving practice: A Practicel Guide. London: SAGE

Osborn, S., Osborn, M., and Osborn, R. (2008). Public Speaking Huidebook. Boston: Pearson.

Presnsky, M. (2001). "Digital Natives, Digital Immigrants”. On the Horizon . (MCB) University Press, Vol. 9. No. 5, October 2001)

Republika.Co.Id. (2018). Kurikulum SD tidak ada mata Pelajaran Bahasa Inggris dan TIK. Koran Republika Online. Retreived from https://m.republika.co.id/amp/mxol

Trent, J. (2009). Enhancing Oral Participation Across the Curriculum: Some Lesson from EAP Classroom. Asian EFL Journal, 11(1). 256-270. Retrieved from http://www.asian-efl-journal.com/march_09-jt.php

Ur, P. (1996). A Course in Language Teaching. Cambridge: Cambridge University Press 
34 Tahuri, Volume 16, Nomor 2, Agustus 2019

Wachidah, S., Gunawan, A., Diyantari. And Khatimah, Y. R. (2017). When English Rings The Bell: Buku guru. Jakarta. Kementerian Pendidikan dan Kebudayaan.

Zaremba, A. J. (2006). Speaking Professionally. Canada: Thompson SouthWestern 